\title{
NEW RECORDS OF HOVER FLIES (DIPTERA, SYRPHIDAE) FROM UKRAINE. IV
}

\author{
A. V. Prokhorov', G. V. Popov², V. Yu. Shparyk ${ }^{3}$ \\ ${ }^{1,2}$ Schmalhausen Institute of Zoology, NAS of Ukraine \\ vul. B. Khmelnytskogo, 15, Kyiv, 01030 Ukraine \\ ${ }^{3}$ Vasyl Stefanyk Precarpathian National University \\ vul. T. Shevchenko, 57, Ivano-Frankivsk, 76018 Ukraine \\ ${ }^{1}$ E-mail: al.val.prokhorov@gmail.com \\ ${ }^{2}$ E-mail: grigory.v.popov@gmail.com \\ ${ }^{3}$ E-mail: viktorshparyk@gmail.com
}

New Records of Hover flies (Diptera, Syrphidae) from Ukraine. IV. Prokhorov, A. V., Popov, G. V., Shparyk, V. Yu. - Six additional species of hover flies of the subfamily Eristalinae are recorded from Ukraine for the first time: Criorhina pachymera Egger, 1858, Hammerschmidtia ferruginea (Fallén, 1817), Melanogaster parumplicata (Loew, 1840), Orthonevra erythrogona (Malm, 1863), Sphiximorpha garibaldii Rondani, 1860, and Temnostoma angustistriatum Krivosheina, 2002. Distributions of these species are summarized and species diagnoses are provided. Updated key to males of the European species of the genus Melanogaster including a little-known M. jaroslavensis (Stackelberg, 1922) is proposed.

Key words: flower flies, Criorhina, Hammerschmidtia, Melanogaster, Orthonevra, Sphiximorpha, Temnostoma, new records, Ukraine.

\section{Introduction}

Hammerschmidtia Schummel, 1834 is the last addition to the list of hover fly genera of Ukraine, currently with 83 genera. In Europe, this genus is represented by two species, one of which, H. ingrica Stackelberg, 1952, was recorded in Europe only from the northeastern parts (Finland and Russia). The second species, $H$. ferruginea (Fallén, 1817), is widespread in Europe (Speight, 2018), but rare and local in many habitats (Rotheray et al., 2008).

Three species of the genus Melanogaster Rondani, 1857 were recorded from Ukraine before this study. These are M. aerosa (Loew, 1843), M. nigricans (Stackelberg, 1922) and M. nuda (Macquart, 1829) (Stackelberg, 1970). In this paper, we provide new records of a fourth species from Ukraine, M. parumplicata (Loew, 1840).

The list of species of the genus Orthonevra Macquart, 1829 is now represented by eight species (Lezhenina et al., in prep.), including O. geniculata (Meigen, 1830) recorded by Prokhorov et al. (2018 b), and O. erythrogona (Malm, 1863) (this study).

The only species of the genus Sphiximorpha Rondani, 1850 recorded so far from Ukraine was S. subsessilis (Illiger in Rossi, 1807) (Popov \& Romanov, 2014). Here we report an unexpected find of Sphiximorpha garibaldii Rondani, 1860 from Kyiv vicinity. 
Four species of the genus Criorhina Meigen, 1822 were known for Ukrainian fauna: C. asilica (Fallén, 1816), C. berberina (Fabricius, 1805), C. floccosa (Meigen, 1822), and C. ranunculi (Panzer, 1804) (Anikina, 1964; Stackelberg, 1970; Prokhorov et al., 2018 a). In present paper we provide new record of a fifth species from Ukraine, C. pachymera Egger, 1858.

Species of the genus Temnostoma Lepeletier \& Serville, 1828 traditionally form two distinct groups (bombylans group and vespiforme group) based on the abdomen shape and body pattern (Krivosheina, 2002). Of the first group, only T. bombylans (Fabricius, 1805) is already a member of the Ukrainian fauna (Stackelberg, 1958). We report a second species of the bombylans group, T. angustistriatum Krivosheina, 2002, collected in the Carpathian mountains. The authors follow the Temnostoma species concepts of Krivosheina (2002), Bartsh et al. (2009), Van Veen (2010), and Speight (2018).

This article continues the series of papers reporting the first records of hover flies from Ukraine (Prokhorov et al., 2017, 2018 a, b, c; Prokhorov \& Popov, 2017).

\section{Material and methods}

All the specimens are deposited in the collection of the I. I. Schmalhausen Institute of Zoology, National Academy of Sciences of Ukraine, Kyiv (Ukraine).

We follow the morphological terminology of Cumming \& Wood (2017). Diagnoses are generally based on the keys by Stackelberg (1953), Maibach et al. (1994), Krivosheina (2002), Bartsh et al. (2009), Van Veen (2010), Van Steenis et al. (2016) and Speight \& Sarthou (2017), and supplemented by the characters we found in this study.

Photographs were taken using a Canon PowerShot A640 camera mounted on Carl Zeiss Stemi 2000 binocular microscope; all images were subsequently combined with Helicon Focus (version 6.0.18) and processed in Adobe Photoshop CS6 by A.V. Prokhorov.

\section{Subfamily Eristalinae \\ Tribe Brachyopini \\ Subtribe Brachyopina}

\section{Hammerschmidtia ferruginea (Fallén, 1817) (figs 1-4)}

Material examined. Ukraine. Rivne Region: Bushcha env.: 50.301 N 26.299 E, edge of deciduous forest, on flowers of Anthriscus sylvestris, 17.05.2018, 1 o; idem, Mizotskyi Kriazh, 50.30 N 26.30 E, deciduous forest, 20-22.05.2019, on flowers of Anthriscus sylvestris, 6 o', 1 ㅇ (A. Prokhorov); Ivano-Frankivsk Region: Tatariv env.: 48.385 N, 24.511 E, Zhenets River valley, 12.06.2018, 1 o; Yaremche env.: 48.443 N, 24.507 E, Zhonka River valley, coniferous forest, on flowers of Chaerophyllum aromaticum, 21.06.2019, 1 ᄋ; Volyn Region: Kivertsi env.: 50.829 N 25.379 E, road in mixed (pinus/oak) forest, on flowers of Anthriscus sylvestris, 08.06.2019, 1 O' (V. Shparyk).

Distribution: Belarus, Bulgaria, Estonia, Finland, France, Germany, Great Britain (Scotland), Hungary, Latvia, Nothern Macedonia, Montenegro, Norway, Poland, Romania, Serbia, Slovakia, Slovenia, Sweden, Switzerland; Russia (European part, Siberia, south of Far East); Transcaucasia; Nearctic Region (from Alaska south to Arizona) (Peck, 1988; Dirickx, 1994; Holinka \& Mazánek, 1997; Reemer, 2000; Stubbs \& Falk, 2002; Stănescu \& Pârvu, 2005; Bartsch et al., 2009; Mielczarek, 2009; Tóth, 2011; Van Steenis et al., 2013; Haarto \& Kerppola, 2014; Barkalov \& Mutin, 2018; Speight, 2018; Wakkie, 2019); Ukraine (first record).

Diagnosis. Both sexes of $H$. ferruginea clearly differ from $H$. ingrica (figs 5-8) by the longer body, $9.0-13 \mathrm{~mm}$ (in $\mathrm{H}$. ingrica, body length $5.5-8.0 \mathrm{~mm}$ ), and plumose arista (fig. 3), with its branches $>2 \times$ as long as the maximum diameter of the arista (in $H$. ingrica, arista with shorter microtrichia (fig. 7), the longest branches slightly longer than the maximum diameter of the arista). Additionally, $H$. ferruginea can be separated from $H$. ingrica by: hind coxae covered with numerous short black setae (Mutin \& Barkalov, 1999) as well as katepisternum with several (8-12) long black setae posteriorly (fig. 4) (in $H$. ingrica, katepisternum without black setae, and hind coxae mostly with 2-3 long black setae only in outer posterior corner laterally and the same amount at the posterior edge, as on fig. 8); female tergite 2 (fig. 2) usually with pale anterolateral part that do not look like separate maculae (in $H$. ingrica, female tergites 2 and often 3 with pale maculae that look like a separate maculae (fig. 6), especially on tergite 2 ). 

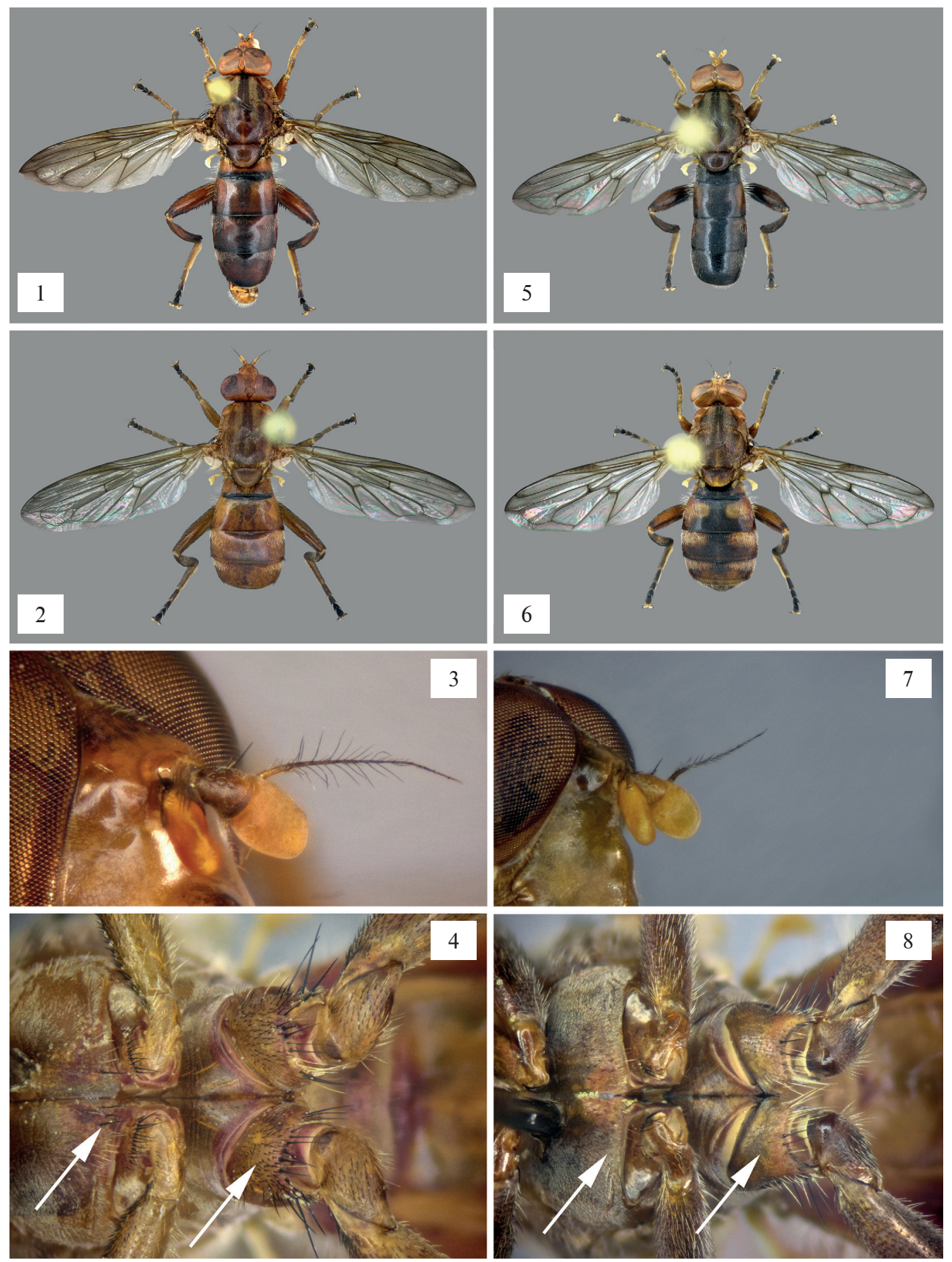

Figs 1-8. Hammerschmidtia ferruginea (figs 1-4) from Rivne Region (Ukraine) and H. ingrica (figs 5-8) from Moscow Region (Russia): 1, 5 - habitus, male, dorsal view; 2, 6- habitus, female, dorsal view; 3, 7 - arista, male, lateral view; 4,8 - thorax, female, ventral view (arrow shows the pilosity of the posterior part of the katepisternum and hind coxa). 
Note. The only representative of the genus in Ukraine. In Great Britain, this species is listed under the UK Biodiversity Action Plan and qualifies as Endangered (Ball \& Morris, 2014).

Melanogaster parumplicata (Loew, 1840) (figs 9, 10, 13, 14, 17, 18)

Material examined. Ukraine. Kyiv Region: Irpin env., 50.51 N 30.27 E, edge of mixed forest along railway, 2.06.2016, 1 \%; Rivne Region: Bushcha env.: 50.30 N 26.25 E, Zbytynka River floodplain, 15.05.2018, 1 O; $50.301 \mathrm{~N} 26.299 \mathrm{E}$, edge of deciduous forest, on flowers of Anthriscus sylvestris, 17.05.2018, 2 ᄋ; idem, 17-22.05.2019, 4 ơ, 7 ○ (A. Prokhorov).

Distribution: uncertain at present, due to confusion with $M$. aerosa (Loew, 1843) until recently, but known from Bosnia-Herzegovina, Czech Republic, Finland, France, Germany, Montenegro, Norway, Poland, Romania, Slovakia, Sweden, Switzerland (Maibach et al., 1994; Holinka \& Mazánek, 1997; Vujić et al., 2001; Stănescu \& Pârvu, 2005; Bartsch et al., 2009; Mielczarek, 2009; Haarto \& Kerppola, 2014; Speight, 2018; Wakkie, 2019); Ukraine (first record).

Diagnosis. Both sexes of M. parumplicata are very similar to M. aerosa (figs 11, 12, $15,16,19,20)$. Male of $M$. parumplicata is similar to $M$. aerosa male in having thorax with black pile and surstyli without elongated apex, differing from $M$. aerosa by: weakly developed flattened facial tubercle (fig. 13) (in M. aerosa, facial tubercle distinctly elongated and pointed, as on fig. 15), scutum shining black (in M. aerosa, scutum, especially notopleuron and lateral side of scutum posterior to transverse suture with a slight bronze or copper tint), face broader (fig. 17), ratio of the maximum head width to the face width at the level just below the antennal base 1.95-2.0 (in M. aerosa, face narrower (fig. 19), this ratio is 2.2), surstylus (in lateral view) shorter and almost straight, with blunt apex (Maibach et al., 1994: fig. 8) (in M. aerosa, surstylus more elongated and slightly curved, with
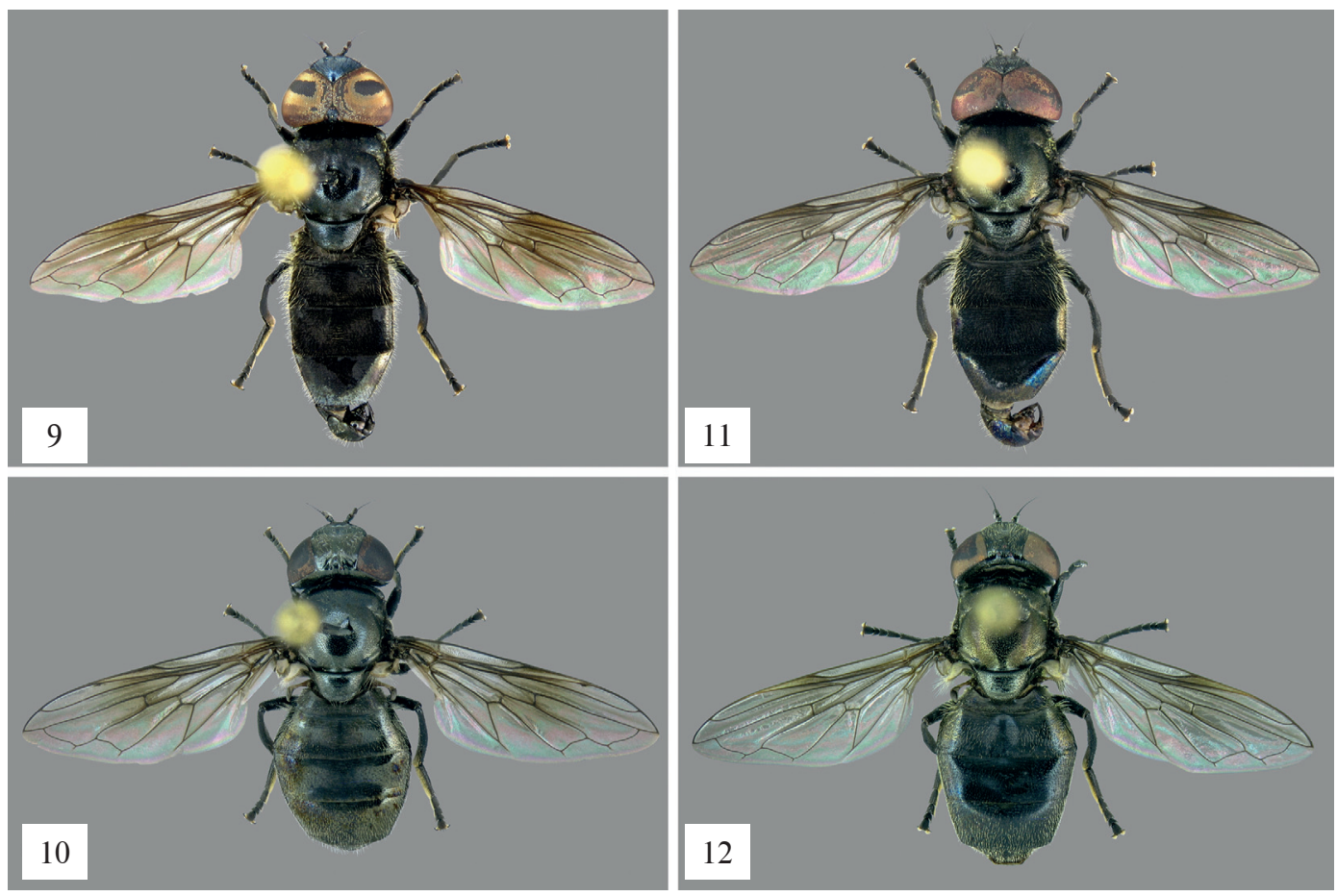

Figs 9-12. Melanogaster parumplicata (figs 9, 10) and M. aerosa (figs 11, 12): 9, 11 - habitus, male, dorsal view; 10, 12 - habitus, female, dorsal view. 

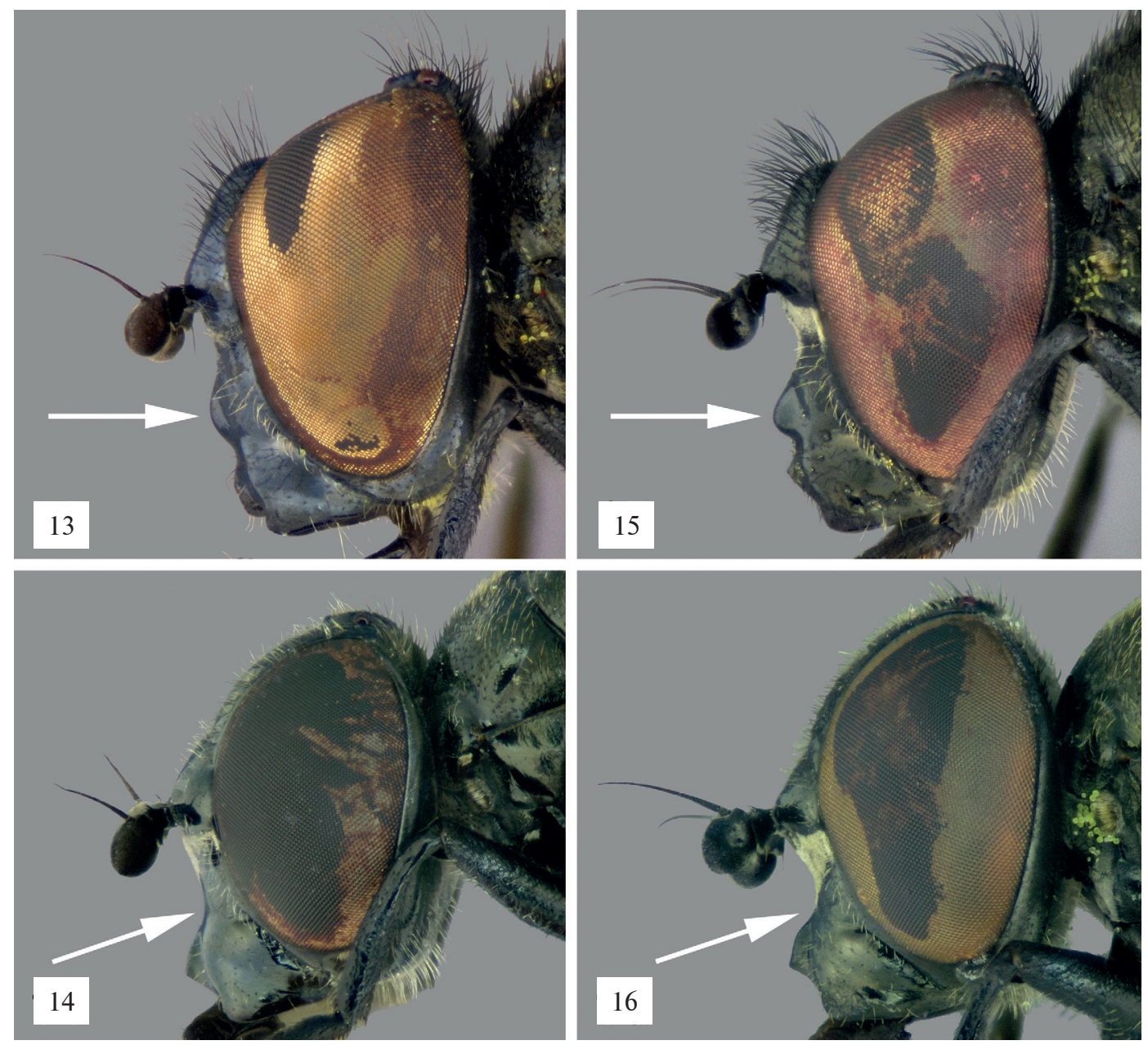

Figs 13-16. Melanogaster parumplicata (figs 13, 14) and M. aerosa (figs 15, 16): 13, 15 - head, male, lateral view (arrow shows facial tubercle); 14, 16 - head, female, lateral view (arrow shows a transition from upper to lower part of the face).

a more pointed apex; Maibach et al., 1994: fig. 3), superior lobe of hypandrium with short appendages (Maibach et al., 1994: fig. 9) (in M. aerosa, superior lobe of hypandrium with long appendages; Maibach et al., 1994: fig. 4). Genitalia of both species are prepared and compared with figures in Maibach et al. (1994). Other characters differing M. parumplicata male from $M$. aerosa male, such as conjunction of the vein $\mathrm{M}_{1}$ with $\mathrm{R}_{4+5}$ or the mesoanepisternal pilosity (Maibach et al., 1994; Van Veen, 2010) seems to be vague in our opinion. The most reliable and convenient characters are the shape and size of the facial tubercle, and genital structures.

Female of $M$. parumplicata is similar to $M$. aerosa female (figs 12, 16, 20) in having mesonotum with short adpressed pale pile; can be distinguished from it by: the scutum shining black (in M. aerosa, scutum is not so shining with bronze or copper tint), tergite 5 with mainly erect to semi-decumbent long pile (Bartsch et al., 2009), their length approximately equal to the width of hind basitarsus (in M. aerosa, tergite 5 with mainly adpressed short pile (Bartsch et al., 2009), their length less than the width of hind basitarsus), transition from upper to lower part of the face (lateral view) is smooth (fig. 14) (Bartsch et al., 2009) (in M. aerosa, transition from upper to lower part of the face is angular, as on fig. 16 (Bartsch et al., 2009)), face broad (fig. 18), ratio of the maximum head width to the face width at the level just below the antennal base 1.9-2.0 (in M. aerosa, face narrow (fig. 20), 

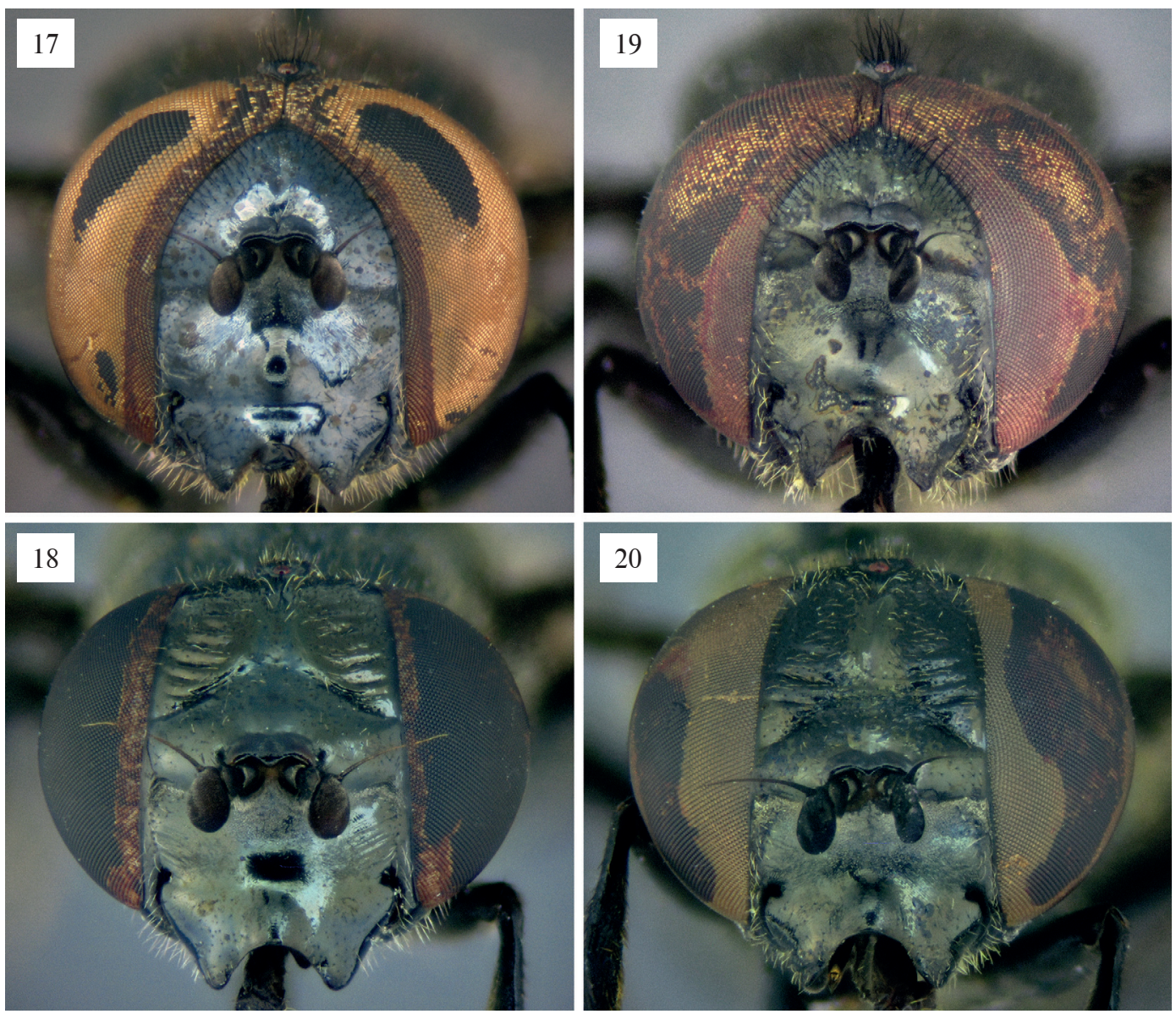

Figs 17-20. Melanogaster parumplicata (figs 17, 18) and M. aerosa (figs 19, 20): 17, 19 - head, male, frontal view; 18, 20 - head, female, frontal view.

this ratio is 2.1-2.15). Unfortunately, transition from upper to lower part of the face varies quite a lot (checked on own material). The clearest characters are shine and coloring of scutum (in females this character is more pronounced than in males), and pilosity of tergite 5.

Note. Listed as a threatened species on the Balkan Peninsula by Vujić et al. (2001).

Here we offer an updated key to males of the European species of the genus Melanogaster including a little-known species M. jaroslavensis (Stackelberg, 1922) with Eastern European distributional range.

\section{Key to males of European Melanogaster}

1 Eyes dichoptic Melanogaster nigricans (Stackelberg, 1922)

- Eyes holoptic.

$2 \quad$ Wing base bright yellow; body dark olive green. ............ Melanogaster jaroslavensis (Stackelberg, 1922)

- Wing base darkened, blackish or brownish; body black.

3 Tergite 8 with short pile (as long as diameter of hind ocellus); surstylus less than twice as long as wide. Melanogaster nuda (Macquart, 1829)

- $\quad$ Tergite 8 with long pile (noticeably longer than diameter of hind ocellus); surstylus 2-3 times longer than wide.

$4 \quad$ Scutum with pale and black pile, pale pile often more abundant. .......................................................... 5

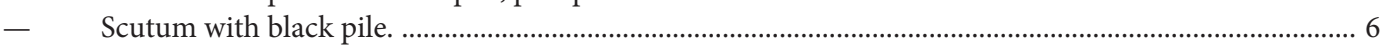

5 Mesonotum covered with long and short pale and black pile mixed; face broad: ratio of the maximum head width to the face width at the level right under the antennal base 1.91-2.08; surstylus with apex not curved. 
- Mesonotum covered with short pale (yellowish) pile almost equally short; face narrow: ratio of the maximum head width to the face width at the level right under the antennal base 2.27-2.37; surstylus with curved apex. ... curvistylus Vujić \& Stuke, 1998

6 Facial tubercle distinctly elongated and pointed (fig. 15); face narrower: ratio of the maximum head width to the face width at the level just below the antennal base 2.2 (fig. 19); scutum, especially notopleuron and lateral side of scutum posterior to transverse suture often with a slight bronze or copper tint. M. aerosa (Loew, 1843)

- $\quad$ Facial tubercle weakly developed and flattened (fig. 13); face broader: ratio of the maximum head width to the face width at the level just below the antennal base 1.95-2.0 (fig. 17); scutum mostly shining black. M. parumplicata (Loew, 1840)
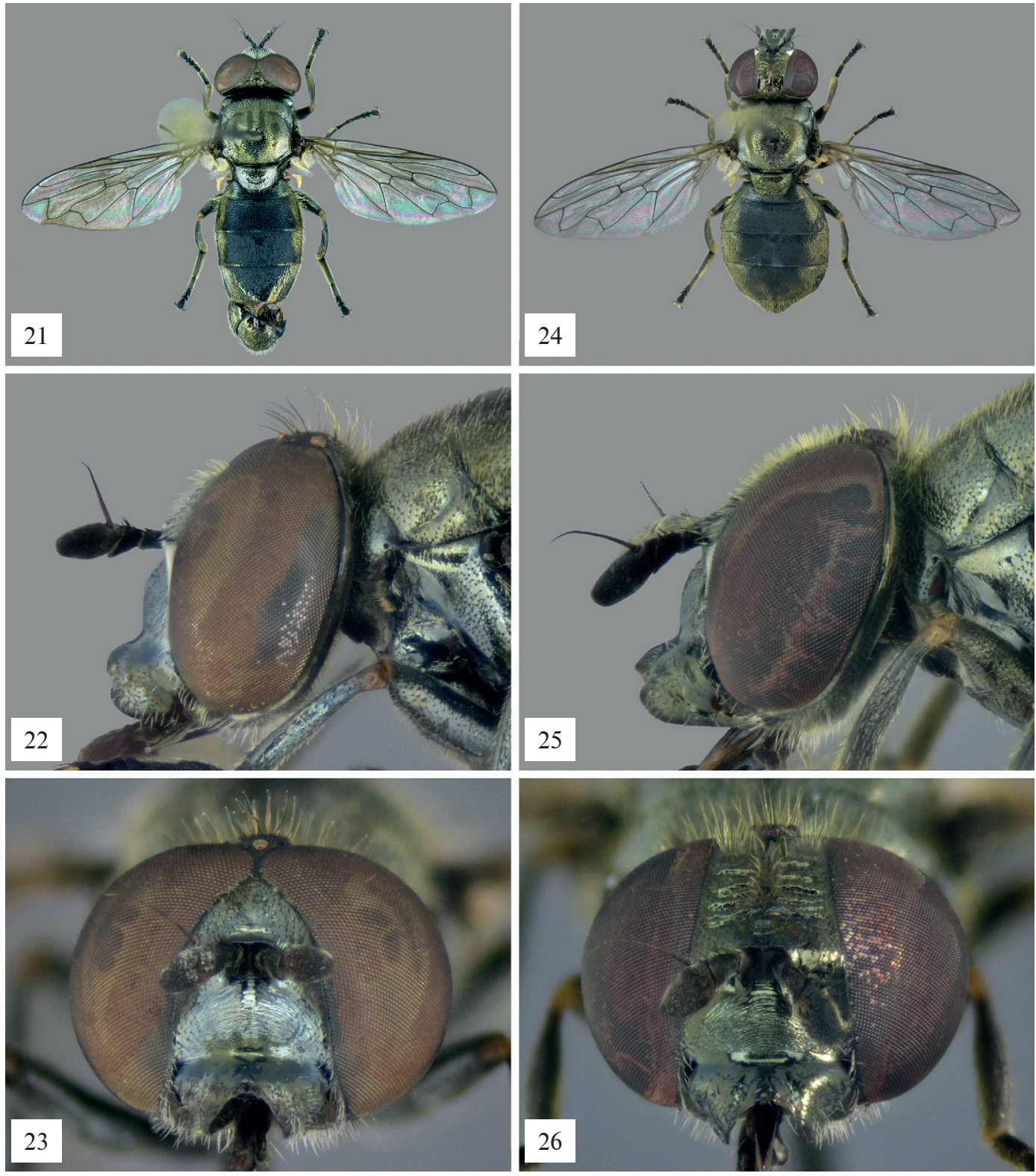

Figs 21-26. Orthonevra erythrogona, male (figs 21-23) and female (figs 24-26): 21, 24 - habitus, dorsal view; 22, 25 - head, lateral view; 23, 26 - head, frontal view. 
Orthonevra erythrogona (Malm, 1863) (figs 21-26)

Material examined. Ukraine. Sumy Region: Matskove env., 51.49 N 33.91 E, Esman River valley, 10-15.05.2018, 4 ơ, 2 \%, 16.07.2018, 1 \% (M. Zaika).

Distribution: Denmark, Estonia, Finland, Germany, Latvia, Lithuania, Norway, Poland, Sweden; Russia (northern and central parts of European Russia, Southern Siberia, Russian Far East); Mongolia (Stackelberg, 1953; Peck, 1988; Bartsch et al., 2009; Mielczarek, 2009; Haarto \& Kerppola, 2014; Barkalov \& Mutin, 2018; Speight, 2018; Wakkie, 2019); Ukraine (first record).

Diagnosis. Both sexes distinctly differ from other Orthonevra species by black legs with pale knees only (figs 21, 22, 24, 25) (in other species, legs either entirely black or tibia pale in basal third and at apex). Orthonevra erythrogona also differs from species with bicolor legs by the basoflagellomere 2 times as long as wide (figs 22, 23, 25, 26) (in other species with bicolor legs, basoflagellomere 3-4 times as long as wide).

\section{Tribe Cerioidini}

\section{Sphiximorpha garibaldii Rondani, 1860 (figs 27-30, 35-38)}

Material examined. Ukraine. Kyiv Region: Irpin env., 50.50 N 30.28 E, Lyubka River floodplain forest, 26.06.2018, on flowers of Filipendula ulmaria, 1 \& (A. Prokhorov).

Distribution. Bulgaria, France, Germany (extinct), Greece, Hungary, Italy, Romania, Serbia, Spain, Turkey (Peck, 1988; Dirickx, 1994; Tóth, 2011; Williams et al., 2011; Saribiyik, 2014; Van Steenis et al., 2016; Ricarte \& Marcos-García, 2017; Speight, 2018; Wakkie, 2019); Ukraine (first record).

Diagnosis. Only four Sphiximorpha species are known from Europe, and S. garibaldii is most similar to S. subsessilis (Illiger in Rossi, 1807) (figs 31-34, 39-42) in having frons with lateral or medial black vittae (Van Steenis et al., 2016) (in S. euprosopa (Loew, 1869), frons entirely yellow). Sphiximorpha garibaldii differs from very rare sub-Mediterranean S. petronillae Rondani, 1850 by the scutellum yellow with black posterior margin (in S. petronillae Rondani, 1850, scutellum entirely yellow). Female of S. garibaldi can be separated from $S$. subsessilis female by: face with a lateral yellow marking in the shape of an inverted hook (usually as on fig. 30) (in S. subsessilis, face with a lateral yellow marking not hook-shaped, as on fig. 34), pedicel shorter (fig. 29), ratio of it length to the width is 1.78 (in S. subsessilis, pedicel longer (fig. 33), ratio of it length to the width is 2.0-2.2), hind femur slender (in S. subsessilis, hind femur ventrally near the apex with a small thickening). These characters were based on Van Steenis et al. (2016), except measurements made on our material. Additionally, S. garibaldi clearly differs from S. subsessilis by the slender tergite 2 (fig. 35): ratio of the length of tergite to its width is 1.77 (in S. subsessilis, tergite 2 more robust (fig. 39), ratio of the length of tergite to its width is 1.25-1.43), distance between yellow maculae on tergite 2 (fig. 35) less than width of the macula (dorsal view) (in S. subsessilis, distance between yellow maculae on tergite 2 more than width of the macula, as on fig. 39), frons with two small transverse yellow maculae separated from lateral maculae (fig. 29) (in S. subsessilis, these maculae are fused with lateral maculae, as on fig. 33), hind femur yellow at base about one sixth of its length (fig. 36) (in S. subsessilis, hind femur yellow at base of at least a third of its length, as on fig. 40), mid basitarsus ventrally with yellow setulae (fig. 37), hind basitarsus entirely pale, and hind tarsus dorsally with only pale macrotrichia (fig. 38) (in S. subsessilis, mid basitarsus ventrally with black setulae (fig. 41), hind basitarsus blackish dorsally, and hind tarsus dorsally with numerous black macrotrichia, as on fig. 42). Our specimen, unlike the description of the species (Van Steenis et al., 2016), with scutellum almost black and with only small orange maculae in anterior edge (fig. 35) (in S. subsessilis, scutellum with broad yellow fascia anteriorly, as on fig. 39). 
Probably some of the above additional characters may vary, for example the color of the pile on tarsus or the presence and shape of yellow maculae on frons, but our specimen clearly differs from S. subsessilis precisely on these characters.

Note. Perhaps this is one of the most incredible new species for the fauna of Ukraine over the past few years because Ukrainian record is so far from the main range of this Southern European species. The specimen was found in a mixed forest with many old trees of
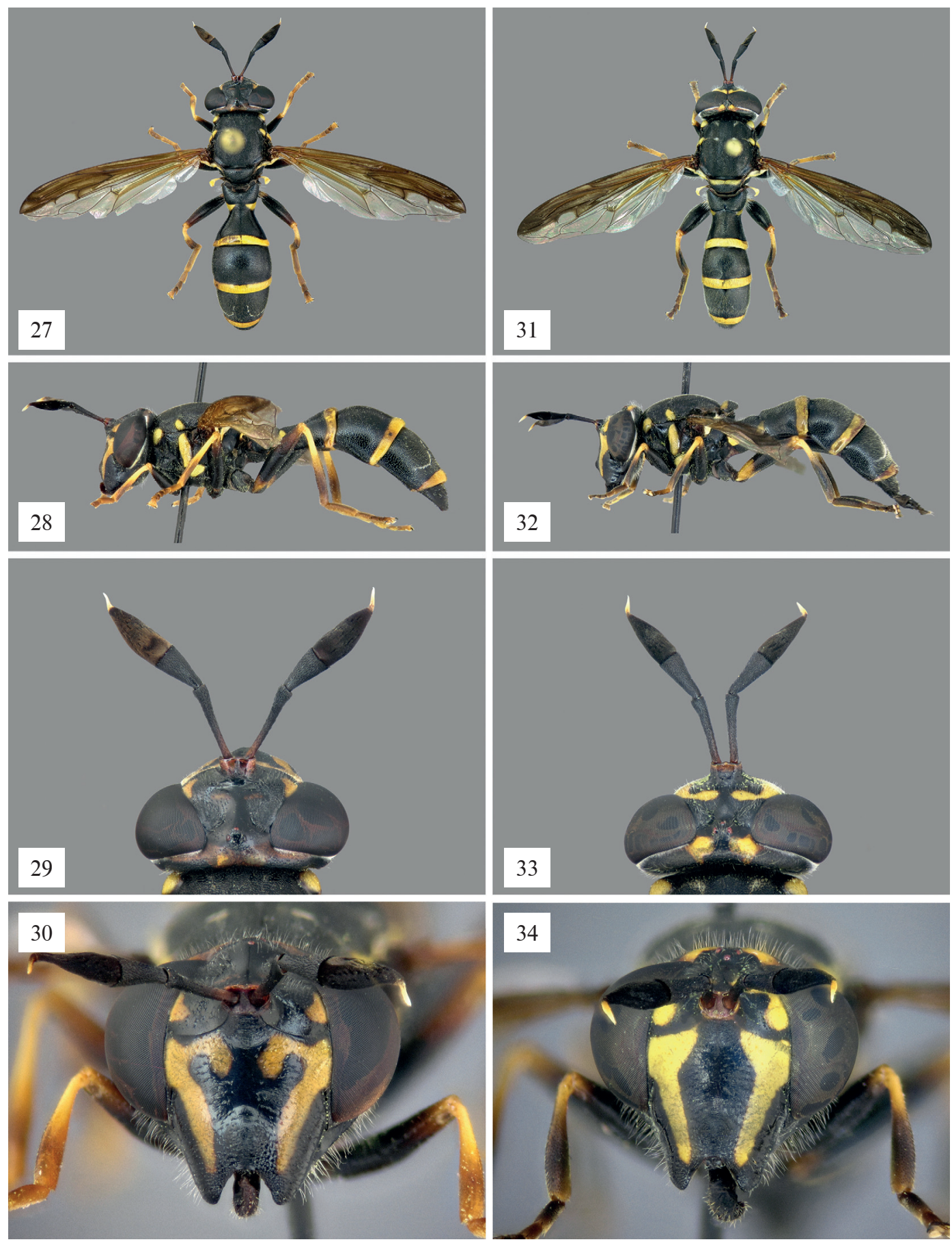

Figs 27-34. Females of Sphiximorpha garibaldii (figs 27-30) and S. subsessilis (figs 31-34): 27, 31 - habitus, dorsal view; 28, 32 - habitus, lateral view; 29, 33 - head, dorsal view; 30, 34 - head, frontal view. 

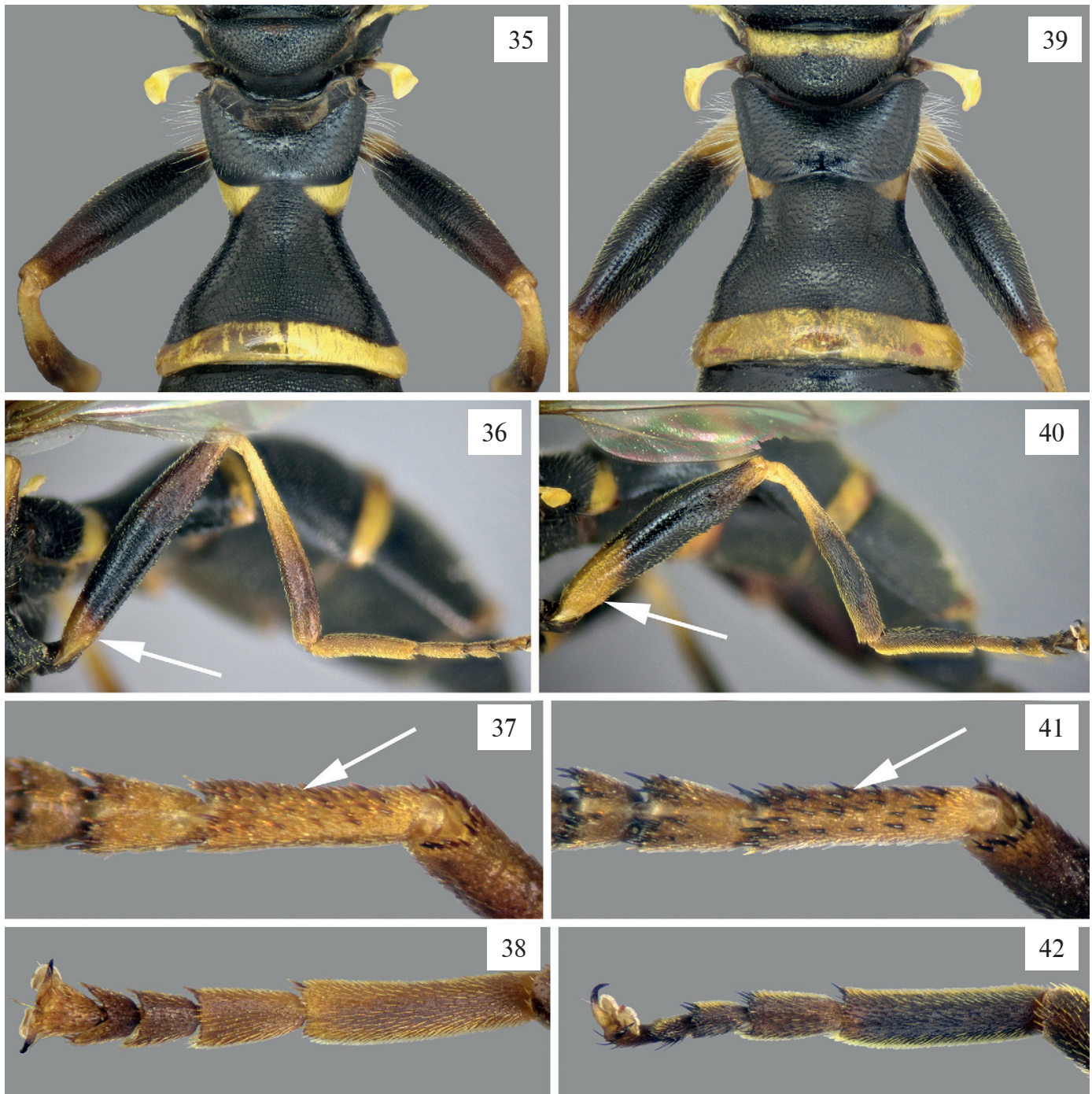

Figs 35-42. Females of Sphiximorpha garibaldii (figs 35-38) and S. subsessilis (figs 39-42): 35, 39 - tergite 2, dorsal view; 36, 40 - hind leg, lateral view (arrow shows the yellow base of the femur); 37, 41 — mid basitarsus, ventral view (arrow shows setulae on ventral side of the tarsomere); 38, 42 - hind tarsus, dorsal view.

Quercus robur, although the preferred environment of this species cited as "thermophilous deciduous forest of Quercus pubescens with overmature trees and Quercus suber forest with overmature trees" (Speight, 2018).

This insect has been very sparsely recorded and is probably threatened at European level (Speight, 2018).

\section{Tribe Milesiini}

\section{Subtribe Criorhinina}

Criorhina pachymera Egger, 1858 (figs 43-46)

Material examined. Ukraine. Rivne Region: Bushcha env., Mizotskyi Kriazh, 50.3019 N 26.3014 E,

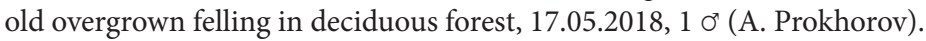



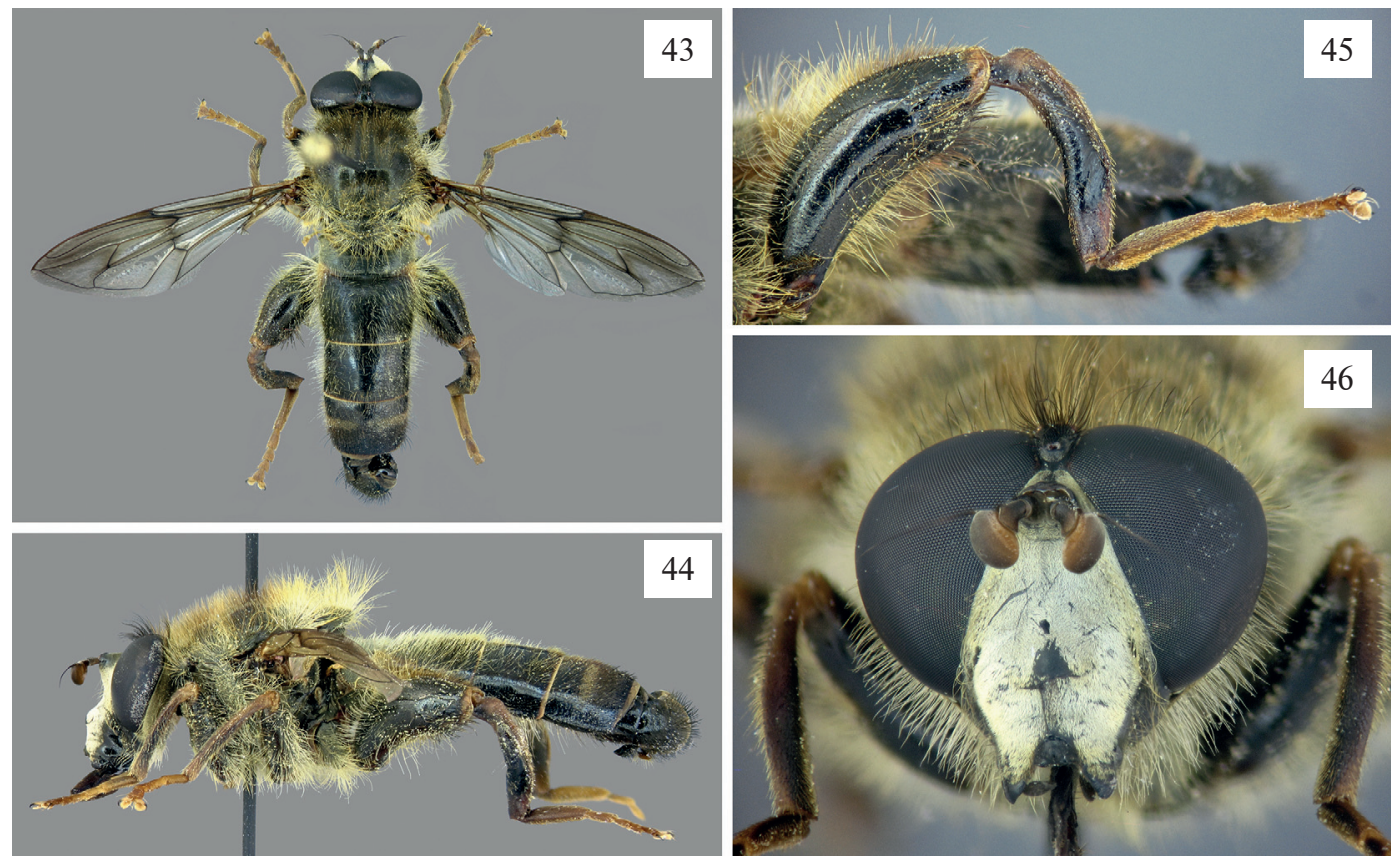

Figs 43-46. Criorhina pachymera male: 43 - habitus, dorsal view; 44 - habitus, lateral view; 45 - hind leg, lateral view; 46 - head, frontal view.

Distribution: Austria, Belgium, Bosnia-Herzegovina, Croatia, Czech Republic, France, Germany, Greece, Hungary, the Netherlands, Poland, Romania, Slovakia, Slovenia, Spain, Sweden, Switzerland (Peck, 1988; Dirickx, 1994; Holinka \& Mazánek, 1997; Vujić et al., 2001; Stănescu \& Pârvu, 2005; De Groot \& Govedič, 2008; Mielczarek, 2009; Reemer et al., 2009; Tóth, 2011; Williams et al., 2011; Johansson, 2015; Ricarte, \& Marcos-García, 2017; Speight, 2018; Wakkie, 2019); Ukraine (first record).

Diagnosis. At first glance, C. pachymera male looks like species of the genus Brachypalpus Macquart, 1834. Among European species of the genus Criorhina Meigen, 1822, it is most similar to C. asilica (Fallén, 1816), C. brevipila Loew, 1871, and C. floccosa (Meigen, 1822), all mimicking bees. Criorhina pachymera can be distinguished from C. floccosa by the hairy katepimeron (in C. floccosa, katepimeron is bare). C. pachymera clearly differs from C. asilica and $C$. brevipila by hind femur thickened, $<5 \times$ as long as their maximum width (fig. 45 ) (in C. asilica and C. brevipila, hind femur slender, $>6 \times$ as long as their maximum width).

Note. Listed as a threatened species on the Balkan Peninsula by Vujić et al. (2001).

\section{Subtribe Temnostomina}

Temnostoma angustistriatum Krivosheina, 2002 (figs 47-50)

Material examined. Ukraine. Zakarpattia: Kvasy env., Carpathian Biosphere Reserve, 48.187 N 24.253 E, Blyznytsya mountain range, beech forest, 20.04-13.05.2019, malaise trap, 2 o; Kozmeschyk env., Carpathian Biosphere Reserve, 48.198 N, 24.459 E, Lazeshchyna River valey, rootholes of old Acerpseudoplatanus, 02.06.2019, 2 O' (V. Shparyk).

Distribution: Finland, Norway; Russia (northern and central European parts, Siberia, south of Far East); Korea, Japan (Krivosheina \& Ståhls, 2003; Haarto \& Kerppola, 2014; Barkalov \& Mutin, 2018; Speight, 2018); Ukraine (first record). 

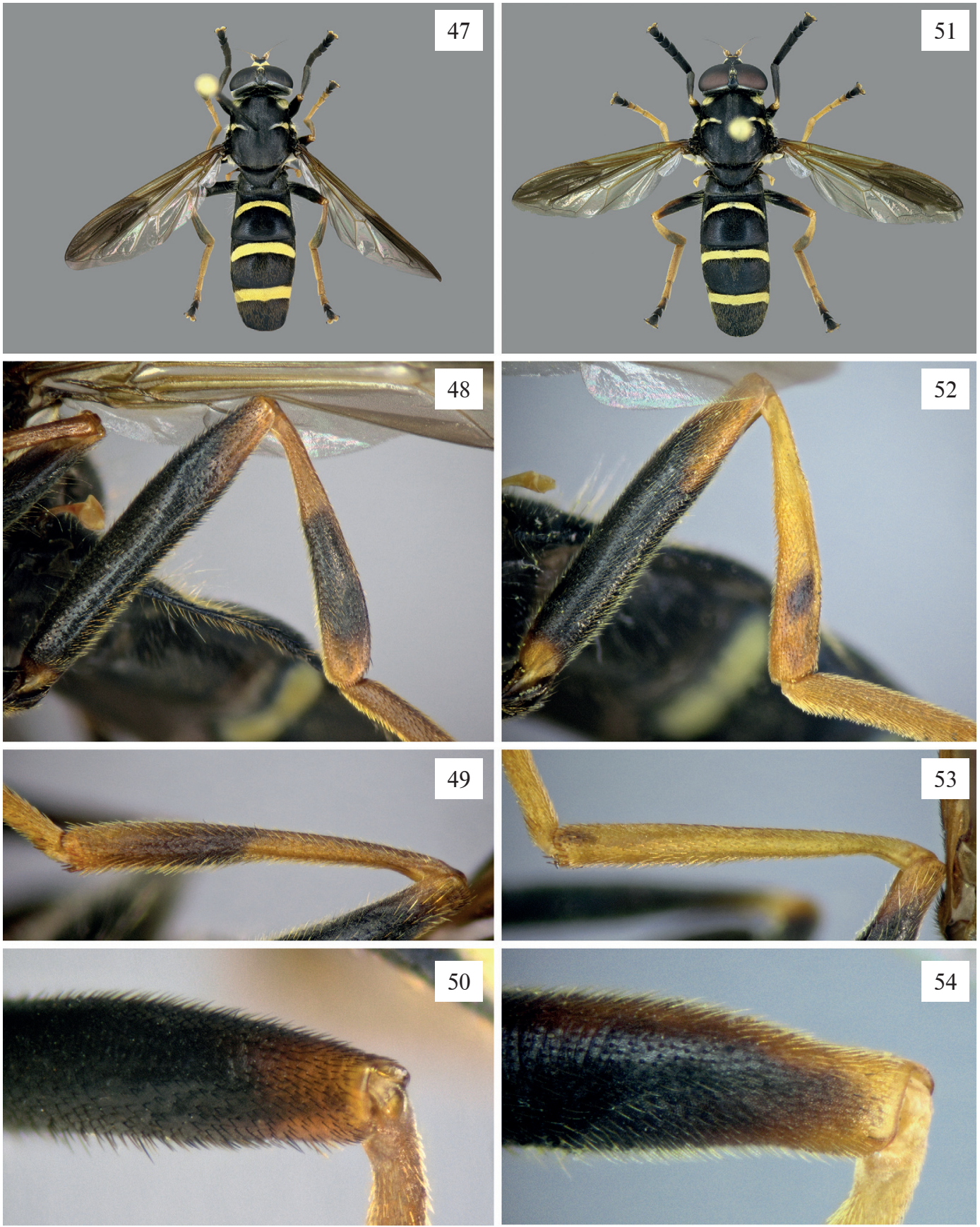

Figs 47-54. Males of Temnostoma angustistriatum (figs 47-50) and T. bombylans (figs 51-54): 47, 51 - habitus, dorsal view; 48, 52 - hind tibia, lateral view; 49, 53 - mid tibia, lateral view; 50, 54 - hind femur, posterodorsal view.

Diagnosis. Body shape, color and markings of T. angustistriatum male are very similar to T. bombylans (Fabricius, 1805) (figs 51-54), but clearly can be distinguished from it by the hind tibia black anterolaterally at least third of the length of the tibia (fig. 48) (in T. bombylans, hind tibia without black mark anterolaterally, or with black mark occupying no more than one sixth of the length of the tibia, as on fig. 52) (Speight \& Sarthou, 2017). Additionally, T. angustistriatum male can be distinguished from T. bombylans by: mid tibia 
yellow with blackish incomplete ring (mostly expressed on the posterior side) just below the middle of tibia not less than a third of the length of the tibia (fig. 49) (in T. bombylans, mid tibia entirely yellow, as on fig. 53), a third of the hind femur at the apex mostly with black macrotrichia (fig. 50) (in T. bombylans, a third of the hind femur at the apex mostly with pale macrotrichia, as on fig. 54). Female can be distinguished by the same characters as the male except mid tibia with less expressed dark ring.

We are very grateful to Oksana Golovko (Dermansko-Ostrozkyi National Park, Rivne Region) for her kind assistance in organizing a collecting trip to the National Park in 2018-2019. The authors thank Myroslav Zaika (Kyiv) for collecting material from Sumy Region. We appreciate two anonymous referees for critical notes and corrections to improve this manuscript.

\section{References}

Anikina, Z. L. 1964. On studying the ecology of hoverflies (Diptera, Syrphidae) of Transcarpathian. In: Fasulati, K. K., ed. Ecology of insects and other terrestrial invertebrates of Soviet Carpathians. Uzhhorod, 3-6 [In Russian].

Ball, S. G. \& Morris, R. K. A. 2014. A review of the scarce and threatened flies of Great Britain. Part 6: Syrphidae. Species status, No. 9, Joint Nature Conservation Committee, Peterborough, 1-130.

Barkalov, A. V. \& Mutin, V. A. 2018. Checklist of the hover-flies (Diptera, Syrphidae) of Russia. Euroasian Entomological Journal, 17 (6), 466-510.

Bartsch, H., Binkiewicz, E., Klintbjer, A., Rådén, A. \& Nasibov, E. 2009. Tvåvingar: Blomfl ugor. Diptera: Syrphidae: Eristalinae \& Microdontinae. Denna volym omfattar samtliga nordiska arter. In: Engström, C. (Chefredaktör), Nationalnyckeln till Sveriges flora och fauna. DH 53 b. ArtDatabanken, Sveriges lantbruksuniversitet, Uppsala, 1-478.

Cumming, J. M. \& Wood, D. M. 2017. Adult morphology and terminology. In: Kirk-Spriggs, A. H. \& Sinclair, B. J., eds. Manual of Afrotropical Diptera. Volume 1. Introductory chapters and keys to Diptera families. Suricata 4, Pretoria, South Africa, 89-133.

De Groot, M. \& Govedič, M. 2008. Checklist of the hoverflies (Diptera: Syrphidae) of Slovenia. Acta entomologica Slovenica, 16 (1), 67-86.

Dirickx, H. G. 1994. Atlas des Diptères syrphides de la région méditerranéenne. Studiedocumenten van het Koninklijk Belgisch Instituut voor Natuurwetenschappen, Documents de travail de l'Institut royal des Sciences naturelles de Belgique. 75, 1-318.

Haarto, A., Kerppola, S. 2014. Checklist of the family Syrphidae (Diptera) of Finland. In: Kahanpää, J., Salmela, J., eds, Checklist of the Diptera of Finland. ZooKeys, 441, 233-249. doi: 10.3897/zookeys.441.7251.

Holinka, J. \& Mazánek, L. 1997. Syrphidae. In: Chvála, M.,ed. Check List of Diptera (Insecta) of the Czech and Slovak Republics. Karolinum Press, Charles University, Prague, 60-66.

Johansson, N. 2015. Brachypalpus valgus and Criorhina pachymera, two spectacular saproxylic hoverflies (Diptera: Syrphidae) new to Northern Europe. Entomologisk Tidskrift, 136 (4), 131-138.

Krivosheina, N. P. 2002. Morphological and faunistic study of xylophilous flower-flies of the bombylans group of the genus Temnostoma (Diptera, Syrphidae). Zoological Journal, 81 (8), 958-969 [In Russian].

Krivosheina, N. P. \& Ståhls, G. 2003. Taxonomy and distribution of Temnostoma bombylans (Fabricius) and T. angustistriatum (Diptera, Syrphidae) in Northern Europe. Sahlbergia, 8, 96-99.

Lezhenina, I. P., Popov, G. V., Prokhorov, A. V., Shparyk, V. Yu. (In prep). Checklist of Ukrainian hover flies (Diptera: Syrphidae).

Maibach, A., Goeldlin de Tiefenau, P. \& Speight, M.C.D. 1994. Limites génériques et caractéristiques taxonomiques de plusieurs genres de la tribu des Chrysogasterini (Diptera: Syrphidae). II. Statut taxonomique de plusieurs des espèces étudiées et analyse du complexe Melanogaster macquarti (Loew). Annales de la Société Entomologique de France (N. S.), 30 (3), 253-271.

Mielczarek, Ł. 2009 (2009-2019). List of species Syrphidae of Poland (Diptera, Syrphidae). Available from: http://syrphidae.insects.pl/checklist.php?lang=en (Accessed: August 29, 2019).

Mutin, V. A. \& Barkalov, A. V. 1999. Fam. Syrphidae - hoverflies. In: Lehr, P. A., ed. Key to the insects of Russian Far East. Vol. 6 (Diptera and Siphonaptera), pt. 1. Dalnauka Publishing House, Vladivostok, 342-500 [In Russian].

Peck, L. V. 1988. Family Syrphidae. In: Soós, Á. \& Papp, L., eds. Catalogue of Palaearctic Diptera, 8 (SyrphidaeConopidae). Elsevier Science Publishers \& Akadémiai Kiadó, Amsterdam, Budapest, 11-230.

Popov, G. V. \& Romanov, G. A. 2014. The first record of the genus Sphiximorpha Rondani (Diptera: Syrphidae) from Ukraine. Ukrainska Entomofaunistyka, 5 (2), 54. 
Prokhorov, A. V. \& Popov, G. V. 2017. The first records of Eristalis picea (Diptera: Syrphidae) from Ukraine and comparison with E. obscura. Ukrainska Entomofaunistyka, 8 (2), 11-15.

Prokhorov, A. V., Popov, G. V. \& Zaika, M. I. 2017. The first records of Melangyna lucifera (Diptera: Syrphidae) from Ukraine. Ukrainska Entomofaunistyka, 8 (1), 16.

Prokhorov, A. V., Popov, G. V. \& Zaika, M. I. 2018 a. New records of hoverflies (Diptera, Syrphidae) from Ukraine. I. Milesiini and Rhingiini. Vestnik Zoologii, 52 (1), 13-20. DOI 10.2478/vzoo-2018-0002

Prokhorov, A. V., Popov, G. V. \& Zaika, M. I. 2018 b. New records of hoverflies (Diptera, Syrphidae) from Ukraine. II. Brachyopini and Merodontini. Vestnik Zoologii, 52 (2): 125-136. DOI 10.2478/vzoo-20180014

Prokhorov, A. V., Popov, G. V. \& Zaika, M. I. 2018 c. New records of hoverflies (Diptera, Syrphidae) from Ukraine. III. Pipizinae and Syrphinae. Vestnik Zoologii, 52 (3): 241-250. DOI 10.2478/vzoo-2018-0025

Reemer, M. 2000. Hoverflies in the Pripyatskij National Park in southern Belarus (Diptera, Syrphidae). Volucella, 5, 139-148.

Reemer, M., Renema, W., Van Steenis, W., Zeegers, T., Barendregt, A., Smit, J. T., Van Veen, M. P., Van Steenis, J. \& Van der Leij, L. J. J. M. 2009. De Nederlandse Zweefvliegen (Diptera: Syrphidae). Nederlandse Fauna 8. Nationaal Natuurhistorisch Museum Naturalis, knnv Uitgeverij, European Invertebrate Survey. Nederland, Leiden, 1-442.

Ricarte, A. \& Marcos-García, M. Á. 2017. A checklist of the Syrphidae (Diptera) of Spain, Andorra and Gibraltar. Zootaxa, 4216 (5), 401-440.

Rotheray, E. L., MacGowan, I., Rotheray, G.E., Sears, J. \& Elliott, A. 2008. The conservation requirements of an endangered hoverfly, Hammerschmidtia ferruginea (Diptera, Syrphidae) in the British Isles. Journal of Insect Conservation, DOI 10.1007/s10841-008-9204-z.

Saribiyik, S. 2014. Checklist of Turkish Flower Flies (Diptera: Syrphidae). Munis Entomology \& Zoology, 9 (1), 570-585.

Speight, M. C. D. 2018. Species accounts of European Syrphidae, 2018. Syrph the Net, the database of European Syrphidae (Diptera), 103, 1-302. Syrph the Net publications, Dublin.

Speight, M. C. D. \& Sarthou, J.-P. 2017. StN keys for the identification of the European species of various genera of Syrphidae 2017. Syrph the Net, the database of European Syrphidae (Diptera), 99, 1-139. Syrph the Net publications, Dublin.

Stackelberg, A. A. 1953. Palaearctic species of the genus Orthoneura Macq. (Diptera, Syrphidae). Entomological Review, 33, 342-357 [In Russian].

Stackelberg, A. A. 1958. List of Diptera of the Leningrad Region. In: Pavlovsky, Ye.N., ed.-in-chief. Materials for study of the fauna and ecology of the Leningrad Region. Proceedings of Zoological Institute, Academy of Sciences of the USSR, Vol. 24. Publishing House of the Academy of Sciences of the USSR, Moscow, Leningrad, 192-246 [In Russian]

Stackelberg, A. A. 1970. Fam. Syrphidae - hoverflies. In: Bey-Biyenko, G. Ya., ed. Key to the Insects of the European part of the USSR, Vol. 5 (Diptera and Siphonaptera), pt. 2. Nauka, Leningrad, 11-96 [In Russian].

Stănescu, C. \& Pârvu, C. 2005. Syrphids (Diptera: Syrphidae) of Romania. Cheklist, phenology, distribution. Travaux du Muséum National d'Histoire Naturelle «Grigore Antipa», 48, 177-202.

Stubbs, A. E. \& Falk, S. J. 2002. British hoverflies: an illustrated identification guide, 2nd edition. British Entomological and Natural History Society, Henry Ling Ltd. The Dorset Press, Dorchester, 1-469.

Tóth, S. 2011. Magyarország zengőlégy faunája (Diptera: Syrphidae) [Hoverfly fauna of Hungary (Diptera: Syrphidae)].e-Acta Naturalia Pannonica, Supplementum 1,1-408.http://epa.oszk.hu/01900/01957/00012/ pdf/EPA01957_e-acta_nat_pannon_suppl_1_2011.pdf

Van Veen, M. P., 2010. Hoverflies of Northwest Europe. Identification keys to the Syrphidae. Second edition. KNNV Publishing, Utrecht, 1-248.

Van Steenis, W., de Groot, M. \& van Steenis, J. 2013. New data on the hoverflies (Diptera: Syrphidae) of Slovenia. Acta entomologica Slovenica, 21 (2), 131-162.

Van Steenis, J., Ricarte, A., Vujić, A., Birtele, D. \& Speight, M. C. D. 2016. Revision of the West-Palaearctic species of the tribe Cerioidini (Diptera, Syrphidae). Zootaxa, 4196 (2), 151-209.

Vujić, A., Šimić, S. \& Radenković, S. 2001. Endangered species of hoverflies (Diptera, Syrphidae) on the Balkan peninsula. Acta entomologica Serbica, 5 (1/2), 93-105.

Wakkie, B. 2019. The world of Syrphidae website. Available from: http://www.syrphidae.com/checklist_ overview.php (Accessed: September 02, 2019).

Williams, M. E. de C., Toussidou, M. \& Speight, M. C. D. 2011. Hoverflies (Diptera, Syrphidae) new to Greece from the Rhodope Mountains of Thrace and eastern Macedonia, including Simosyrphus scutellaris new to Europe. Dipterists Digest, 18, 181-198.

Receved 1 October 2019

Accepted 25 October 2019 